\title{
MEDICATION OVERUSE HEADACHE, WHY IT HAPPENED?
}

\author{
Restu Susanti ${ }^{1)}$ \\ ${ }^{1}$ Fakultas Kedokteran, Universitas Andalas, RSUP Dr. M.Djamil Padang, Jl.Perintis Kemerdekaan, Sawahan \\ Timur, Padang Timur, Kota Padang \\ email: restususanti@yahoo.com
}

Submitted : 17-02-2020, Reviewer:20-02-2020, Accepted: 21-02-2020

\begin{abstract}
Medication Overuse Headache (MOH) is a secondary headache -- worsening condition of preexisting headache (usually primary hedache). MOH occurs due to medication overuse to relief the pain or to treat the headache attack. The etiology of $\mathrm{MOH}$ is the excessive use of single and combined analgesics, nonsteroidal anti-inflammatory drugs, caffeine, opioids, ergotamine, triptans and barbiturates. MOH is a chronic headache which need to recognize early. Diagnosis, accurate therapy, and management of comorbidities must be done to improve patient's productivity and quality of life.
\end{abstract}

Keywords: $\mathrm{MOH}$, headache, analgesic

\begin{abstract}
Abstrak
Medication Overuse Headache (MOH) merupakan nyeri kepala sekunder - suatu perburukan dari nyeri kepala yang sudah ada sebelumnya (biasanya nyeri kepala primer). Terjadi akibat penggunaan berlebihan satu atau lebih obat-obatan untuk mengatasi serangan atau menghilangkan rasa nyeri tersebut. Penggunaan berlebihan analgesik tunggal dan kombinasi, antiinflamasi nonsteroid, kafein, opioid, ergotamin, triptan dan barbiturate menjadi penyebab MOH. MOH merupakan nyeri kepala kronik yang harus dikenali sejak dini. Diagnosis, terapi akurat dan tatalaksana komorbid harus dilakukan untuk memperbaiki kualitas hidup dan produktivitas pasien.
\end{abstract}

Keywords: $\mathrm{MOH}$, nyeri kepala, analgesik

\section{PENDAHULUAN}

Menurut konsep saat ini, nyeri kepala akibat penggunaan obat yang berlebihan (Medication Overuse Headache) [MOH] merupakan nyeri kepala sekunder — suatu perburukan dari nyeri kepala yang sudah ada sebelumnya (biasanya nyeri kepala primer). Terjadi akibat penggunaan berlebihan satu atau lebih obat-obatan untuk mengatasi serangan atau menghilangkan rasa nyeri tersebut. Konsep bahwa pengobatan nyeri kepala mungkin menjadi penyebab kronifikasi dari nyeri kepala bukanlah hal baru, tetapi pemahaman kita tentang konsep ini,dan terminologi yang mendefinisikannya, telah berubah sepanjang tahun. ${ }^{1-3}$
Kriteria $\mathrm{MOH}$ didasarkan pada konsensus ahli dan bukan bukti formal. Menurut International Classification of Headache Disorders-3 beta terbaru, $\mathrm{MOH}$ pada dasarnya didefinisikan sebagai nyeri kepala selama 15 hari atau lebih per bulan yang dianggap sebagai konsekuensi dari penggunaan obat nyeri kepala yang terlalu sering digunakan pada pasien dengan nyeri kepala yang sudah ada sebelumnya. Klasifikasi tidak termasuk jumlah unit obat atau dosis yang digunakan, tetapi jumlah hari per bulan obat diminum. ${ }^{1-3}$

Medication Overuse Headache $(\mathrm{MOH})$ merupakan masalah umum kesehatan global dengan prevalensi pada populasi dewasa dari berbagai negara mulai 
dari $0,5 \%$ hingga $7,6 \%$. Data dari Skandinavia menunjukkan prevalensi $1 \%$ hingga 2\%, mewakili sekitar 50\% dari semua pasien dengan nyeri kepala harian kronis $(\mathrm{CDH})$, nyeri kepala terjadi pada 15 hari atau lebih per bulan selama lebih dari 3 bulan). $\mathrm{MOH}$ jelas dominan terjadi pada wanita. Dibandingkan dengan tidak ada nyeri kepala atau nyeri kepala episodik, $\mathrm{MOH}$ dan nyeri kepala kronis harian lainnya menyebabkan penurunan yang signifikan dalam kualitas hidup dan produktivitas di tempat kerja. Gangguan psikiatri dan stresor terkait lainnya memiliki efek negatif ditambah lagi dengan penggunaan obat berlebihan justru akan menambah masalah pasien. ${ }^{4-10}$

Dokter harus selalu mencurigai $\mathrm{MOH}$ pada pasien yang sering melaporkan nyeri kepala, terutama jika ada riwayat migraine dan nyeri kepala tipe tegang sebelumnya. Penting untuk dicatat bahwa nyeri kepala di MOH tidak memiliki fitur unik. Banyak pasien menggunakan obat pereda nyeri kurang atau lebih dari keteraturan seharusnya. Justru mengantisipasi nyeri kepala daripada mengobati nyeri kepala itu sendiri, harus menimbulkan kekhawatiran. ${ }^{11}$

\section{DEFINISI}

Menurut International Classification of Headache Disorders-3 beta terbaru, $\mathrm{MOH}$ pada dasarnya didefinisikan sebagai nyeri kepala selama 15 hari atau lebih per bulan yang dianggap sebagai konsekuensi dari penggunaan obat nyeri kepala yang terlalu sering digunakan pada pasien dengan nyeri kepala yang sudah ada sebelumnya. Klasifikasi tidak termasuk jumlah unit obat atau dosis yang digunakan, tetapi jumlah hari per bulan obat diminum. ${ }^{1-3}$

Definisi MOH yang lebih spesifik adalah nyeri kepala yang terjadi pada $\geq 15$ hari per bulan sebagai akibat dari terlalu sering menggunakan obat nyeri kepala akut atau simtomatik $(\geq 10$ hari per bulan untuk triptan, ergotamin, atau opioid; $\geq 15$ hari per bulan untuk analgesik sederhana atau kombinasi) selama lebih dari 3 bulan. Biasanya, tetapi tidak selalu, diselesaikan setelah penggunaan yang berlebihan dihentikan. ${ }^{12}$

\section{EPIDEMIOLOGI}

Medication Overuse Headache merupakan masalah umum kesehatan global dengan prevalensi pada populasi dewasa dari berbagai negara mulai dari $0,5 \%$ hingga 7,6\%. Penelitian di Skandinavia melaporkan prevalensi $\mathrm{MOH} 1 \%$ hingga 2\%, mewakili sekitar $50 \%$ dari semua pasien dengan nyeri kepala harian kronis ([CDH]), nyeri kepala terjadi pada 15 hari atau lebih per bulan selama lebih dari 3 bulan). Di Singapura, survei praktik umum pasien dan dokter yang hadir dalam pengaturan perawatan primer menemukan bahwa $22,6 \%$ populasi pasien melaporkan minum obat nyeri akut untuk nyeri kepala setidaknya 4 hari per minggu. Namun, dokter hanya mengidentifikasi hal ini pada 5,3\% dari populasi penelitian, menunjukkan bahwa dokter tidak mengenali sebagian besar pasien yang berisiko $\mathrm{MOH} .{ }^{4-}$ 10,13-14

Prevalensi untuk $\mathrm{MOH}$ di tingkat populasi umum ditempatkan antara 1 dan $2 \%$, dengan kisaran antara $0,5 \%$ dan $7,2 \%$. Prevalensi tertinggi telah ditunjukkan di Rusia (7,2\%). Pengetahuan tentang prevalensi dan beban sosial-ekonomi di negara-negara kurang berkembang telah sangat terbatas sejak lama, meskipun penelitian telah diterbitkan akhir-akhir ini untuk prevalensi di Afrika (Zambia 7,1\%; Ethiopia 0,7\%), Amerika Latin (Brasil 1,4\%, Kolombia $4.3 \%$ ) dan Asia (Korea 0,5\%; Cina 0,6\%). $\mathrm{MOH}$ diperkirakan mempengaruhi sekitar 63 juta orang di seluruh dunia. Prevalensi penggunaan obat yang berlebihan lebih tinggi dalam penelitian dari pusat spesialis nyeri kepala, 
dengan jumlah berkisar antara $30 \%$ hingga $50 \%$ dari pasien. ${ }^{4-10,13-14}$

Tinjauan sistematis dari studi epidemiologi melaporkan $\mathrm{MOH}$ paling umum di antara dewasa paruh baya dari usia 30 hingga 50 tahun, dan dominan pada wanita dalam sebagian besar studi. Prevalensi MOH lebih besar pada perempuan daripada laki-laki. Rasio pria terhadap wanita adalah sekitar 1 hingga 3-4. Prevalensi tertinggi pada dekade keempat kehidupan, tampaknya menurun setelahnya. Dilaporkan antara $21 \%$ dan $52 \%$ pasien anak dengan nyeri kepala kronis memenuhi kriteria untuk MOH. Di seluruh dunia, prevalensi $\mathrm{MOH}$ dalam sampel pediatrik adalah 3,3\%,0,3\%,0,5\% dan 1,6\% masingmasing di Italia, Taiwan, Norwegia dan Kanada. Dalam populasi lansia, penelitian dari beberapa pusat nyeri kepala menemukan bahwa sekitar 35\% dari pasien yang lebih tua dari 64 tahun menggunakan obat secara berlebihan. ${ }^{4-10,13-14}$

\section{FAKTOR RISIKO}

Sebagian besar dari apa yang kita ketahui tentang faktor risiko untuk $\mathrm{MOH}$ berasal dari studi potong lintang, yang membuatnya sulit untuk memastikan apakah faktor yang diidentifikasi adalah penyebab atau efek dari nyeri kepala kronis. Penggunaan obat berlebihan ditemukan menjadi faktor risiko penting untuk kronifikasi nyeri kepala primer. Risiko terendah untuk triptan (risiko relatif (RR) 0,65) dan ergotamin (RR 0,41) dibandingkan dengan analgesik gabungan. Triptan dan obat yang mengandung ergotamin ditemukan lebih baik bila dibandingkan dengan opioid. Ini sejalan dengan Bigal et al. yang melaporkan bahwa orang yang menggunakan obat yang mengandung barbiturat atau opiat memiliki risiko dua kali lipat lebih tinggi untuk mengalami nyeri kepala kronis daripada pasien yang menggunakan analgesik tunggal atau triptan. Dalam penelitian Vandenbussche et al., NSAID efektif terhadap pengembangan nyeri kepala kronis pada tingkat rendah dari hari-hari nyeri kepala bulanan, tetapi dikaitkan dengan peningkatan risiko mengembangkan nyeri kepala kronis pada pasien dengan tingkat tinggi hari nyeri kepala bulanan (lebih dari 10 hari per bulan). ${ }^{14-16}$

Ditemukan hubungan $\mathrm{MOH}$ dengan tingkat penghasilan, pendidikan yang rendah, merokok, gangguan tidur, dan indeks massa tubuh yang tinggi. Depresi dan kecemasan lebih umum pada pasien dengan $\mathrm{MOH}$ dibandingkan pada mereka dengan migrain episodik. Risiko terjadinya $\mathrm{MOH}$ lebih besar pada orang-orang dengan riwayat keluarga $\mathrm{MOH}$ atau terlalu banyak menggunakan zat. Adanya nyeri kepala primer yang sudah ada sebelumnya, merupakan factor risiko penting untuk diagnosis $\mathrm{MOH}$. Migrain adalah kelainan yang mendasarinya pada sekitar 60\% hingga $80 \%$ pasien, dan beberapa penulis berpendapat bahwa mekanisme patofisiologis yang terlibat dalam migrain juga ada pada MOH. ${ }^{1}$

Studi neurofisiologis menunjukkan adanya neuronal hyperexcitability dengan bukti kepekaan dari jalur nosiseptif perifer dan sentral pada hewan yang terpapar obat penghilang rasa nyeri telah menjelaskan patofisiologi kompleks $\mathrm{MOH}$, tetapi mekanisme jelas belum ditemukan. Polimorfisme pada beberapa gen yang mengkode enzim pengubah angiotensin, faktor neurotropik, katekol-Ometiltransferase, dan serotonin transporter, telah dikaitkan dengan $\mathrm{MOH}$, tetapi hubungan tersebut masih harus dipahami. ${ }^{1}$

\section{OBAT - OBATAN YANG BERHUBUNGAN DENGAN MOH}

Penggunaan obat berlebihan ditemukan menjadi faktor risiko penting untuk kronifikasi nyeri kepala primer. 
Berikut yang obat dikaitkan dengan $\mathrm{MOH}$ : analgesik sederhana (asetaminofen, dan asam asetilsalisilat (ASA) yang lebih jarang) dan obat antiinflamasi nonsteroid (NSAID), kafein, opioid, analgesik kombinasi, ergotamin, triptan dan barbiturat (terutama di AS dan Kanada). Risiko dari terendah ke tertinggi adalah: triptan / ergotamin, agen analgesik tunggal (NSAID, asetaminofen), dan analgesik kombinasi yang mengandung opiat atau barbiturat. Risiko terendah untuk triptan (risiko relatif (RR) 0,65) dan ergotamin (RR 0,41) dibandingkan dengan analgesik gabungan. Triptan dan obat yang mengandung ergotamin ditemukan lebih baik bila dibandingkan dengan opioid. Ini sejalan dengan Bigal et al. yang melaporkan bahwa orang yang menggunakan obat yang mengandung barbiturat atau opiat memiliki risiko dua kali lipat lebih tinggi untuk mengalami nyeri kepala kronis daripada pasien yang menggunakan analgesik tunggal atau triptan. ${ }^{15-16}$ Penggunaan opioid dan triptan secara kronis telah terbukti meningkatkan kadar Calsitonin Gen Related Peptide (CGRP) yang terlibat dalam inflamasi neurogenik dan nyeri kepala. ${ }^{17,20-22}$

\section{PATOFISIOLOGI}

Pemahaman lengkap tentang patofisiologi $\mathrm{MOH}$ masih belum jelas. Meskipun aspek klinis MOH tampaknya ambivalen, terdapat bukti aspek neurobiologis spesifik berperan pada $\mathrm{MOH}$. Studi pada hewan, studi genetik, neuroimaging struktural dan fungsional, dan analisis elektrofisiologi telah menambah pengetahuan saat ini tentang patofisiologi MOH (Gambar 2.1). ${ }^{14}$

Penelitian pada hewan telah menunjukkan perubahan dalam beberapa proses fisiologis dalam sistem saraf pusat (SSP) setelah pemberian analgesik berulang. Paparan sumatriptan kronis meningkatkan kerentanan jangka panjang aktivasi Cortical Spreading Depression (CSD) akibat penurunan ambang. Upregulation mediator vasoaktif dan pro-inflamasi seperti Calcitonin-Related Peptide (CGRP),

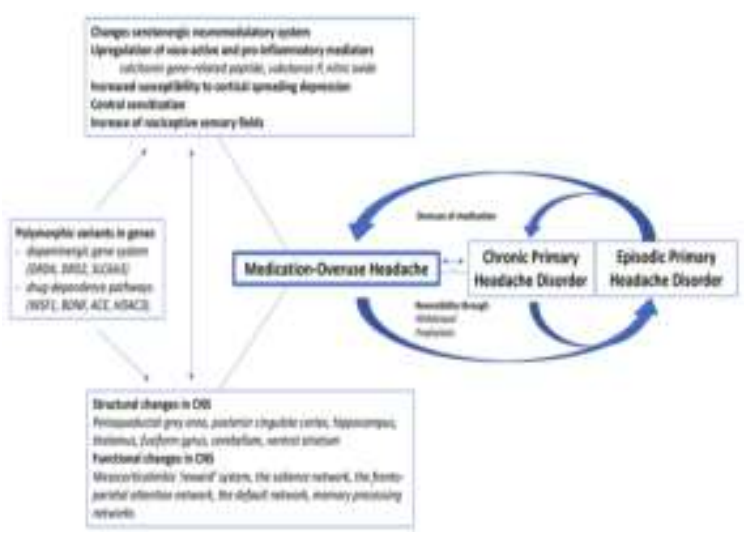

substansi $\mathrm{P}$, dan nitrit oksida ditemukan di ganglia trigeminal. Perluasan bidang nosiseptif reseptif, penurunan ambang nosiseptif dan penurunan kontrol hibridik yang berbahaya telah dilaporkan. Selain itu, paparan kronis untuk analgesik ditemukan meningkatkan rangsangan neuron di inti amigdala, yang dapat membuat konsep perkembangan kecemasan atau depresi pada pasien dengan $\mathrm{MOH}$.

Sistem modulasi serotonergik mungkin dipengaruhi oleh penggunaan analgesik kronis. Terjadi hipereksitasi neuron, peningkatan CSD dan nosiseptor trigeminal disebabkan oleh peningkatan ekspresi serotonin pro-nociceptive 2A (5HT2A) dan penurunan produksi serotonin dalam sistem saraf. Dalam analisis temuan pada hewan, upregulasi reseptor 5HT-2 pada membran trombosit selama penyalahgunaan analgesik dan kadar trombosit serotonin yang lebih rendah ditemukan, mungkin disebabkan oleh penekanan transportasi serotonin. ${ }^{14}$

Dalam tinjauan sistematis terbaru, Cargnin et al. mendeskripsikan varian kandidat polimorfik pada gen sistem gen dopamin (DRD4, DRD2, SLC6A3), dan gen yang terkait dengan jalur ketergantungan obat (WSF1, BDNF, ACE, HDAC3). Mereka menyimpulkan bahwa sifat-sifat ini 
adalah faktor risiko potensial untuk kerentanan atau faktor penentu dari konsumsi obat setiap bulan. ${ }^{14}$

Selama dekade terakhir, studi pencitraan telah meningkatkan pengetahuan tentang perubahan struktural dan kejadian fisiologis pad $\mathrm{MOH}$. Studi pencitraan struktural yang dilakukan oleh kelompokkelompok terpisah telah menemukan peningkatan volume gray matter pada daerah periaquaductal gray (PAG), korteks posterior singulata, hipokampus, thalamus, gyrus fusiformis, serebelum dan ventri striatum. Volume yang lebih sedikit ditemukan di orbitofrontal cortex (OFC), anterior cingulate cortex, gyrus oksipital tengah kiri, insula dan precuneus. Struktur ini terlibat dalam modulasi dan pemrosesan nyeri, kognisi, perilaku afektif, kecanduan dan kesadaran. Sebuah studi baru-baru ini menggambarkan gangguan dalam integritas white matter di korteks insular dan di operculum parietal. Pada $\mathrm{MOH}$, perubahan konektivitas dan struktur fungsional dapat bersifat reversibel di beberapa daerah tetapi tidak semua dan kadang-kadang menjadi normal setelah perawatan. ${ }^{14}$

\section{KRITERIA DIAGNOSIS}

Berikut yang obat dikaitkan dengan MOH: analgesik sederhana (asetaminofen, dan asam asetilsalisilat (ASA) yang lebih jarang) dan obat antiinflamasi nonsteroid (NSAID), kafein, opioid, analgesik kombinasi, ergotamin, triptan dan barbiturat (terutama di AS dan Kanada) dan kriteria diagnosis $\mathrm{MOH}$ menurut International Headache Society dijelaskan dalam tabel $1 .{ }^{17}$

Hubungan antara "penggunaan berlebihan" dan memburuknya nyeri kepala yang sudah ada sebelumnya didasarkan pada asumsi, dan perbaikan setelah penghentian penggunaan obat yang berlebihan tidak lagi diperlukan untuk membuat diagnosis $\mathrm{MOH}$. Pemahaman tentang $\mathrm{MOH}$ didasarkan pada gagasan bahwa harus ada nyeri kepala (primer) yang mendasari hal tersebut, dan bahwa ada juga penyebab sekunder, dan

Tabel 1 Kriteria Diagnosis $\mathrm{MOH}$ menurut International Headache Society. ${ }^{17}$

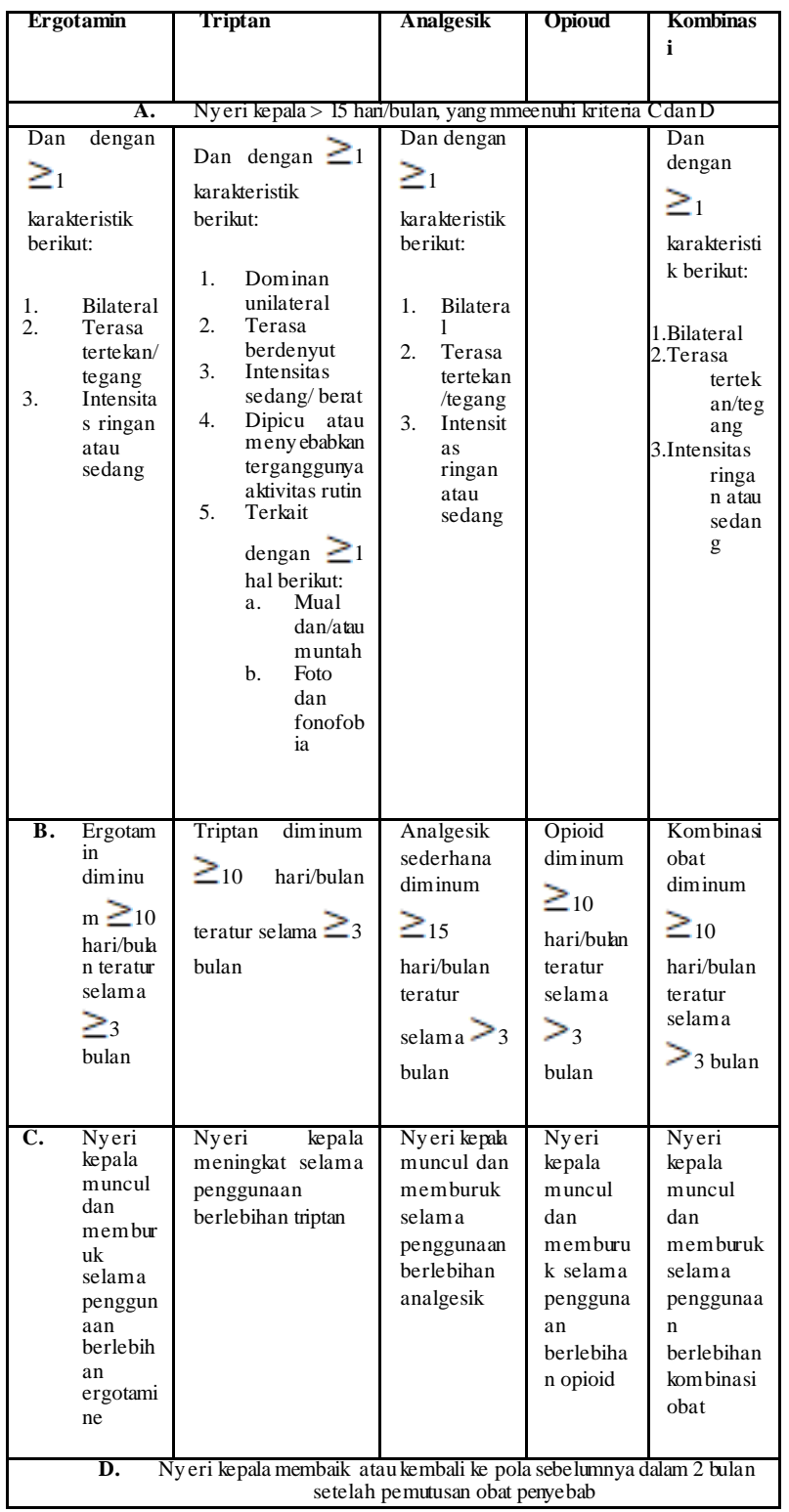

oleh karena itu pasien menerima diagnosis nyeri kepala primer dan sekunder, seperti $\mathrm{MOH}$ dan migrain kronis. Jika penghentian obat mengubah kondisi kronis menjadi episodik, diagnosis $\mathrm{MOH}$ mungkin akurat. Jika tetap kronis, diagnosis $\mathrm{MOH}$ mungkin saja salah, tetapi tidak harus demikian. Dapat dibayangkan, pada beberapa pasien, 
penggunaan obat secara berlebihan mungkin memiliki efek berbahaya yang berlangsung lama pada nyeri kepala, dan karenanya dapat menjadi faktor penyebab bahkan ketika penghentian tidak mengurangi frekuensi nyeri kepala. Bagaimanapun, kondisi ini memprihatinkan karena terlalu lama menggunakan analgesik sederhana dapat menimbulkan efek samping yang serius. Nyeri kepala sekunder lainnya, seperti yang disebabkan oleh peningkatan tekanan intrakranial, tidak boleh diabaikan. Jadi, pada tindak lanjut, mungkin penting untuk meninjau diagnosis nyeri kepala. Masalah khusus yang mungkin muncul dikenal sebagai "nyeri kepala persisten harian baru," yang merupakan nyeri kepala yang unik dalam arti bahwa itu setiap hari sejak onset, tak henti-hentinya dalam waktu 24 jam, dan tahan lama. Ini terjadi secara khas, tetapi tidak secara eksklusif, pada individu tanpa riwayat nyeri kepala sebelumnya. ${ }^{1}$

Pemeriksaan neurologis klinis pada pasien dengan $\mathrm{MOH}$ direkomendasikan dan seharusnya normal. Membuat buku harian nyeri kepala dengan informasi terperinci tentang penggunaan obat selama minimal 4 minggu adalah alat yang sangat membantu untuk mendokumentasikan MOH. Dokter harus memesan pencitraan otak hanya jika mereka mencurigai adanya nyeri kepala sekunder lainnya. Ketika memutuskan bagaimana merawat pasien, kita mungkin menemukan bahwa berguna untuk mengelompokkan pasien menjadi 2 kelompok: kasus yang relatif tidak rumit (tipe I, tidak ada gangguan perilaku dan tidak ada penggunaan barbiturat atau opioid) dan kasus rumit (tipe II, masalah psikologis yang signifikan dan / atau terlalu sering menggunakan barbiturat dan / atau opioid). Kita juga dapat menganggap pasien dengan kegagalan penarikan sebelumnya sebagai kasus yang rumit. ${ }^{1}$
Tabel 2 Kriteria Diagnosis $\mathrm{MOH}$ menurut International Classification of Headache Disorders-3 beta ${ }^{1}$

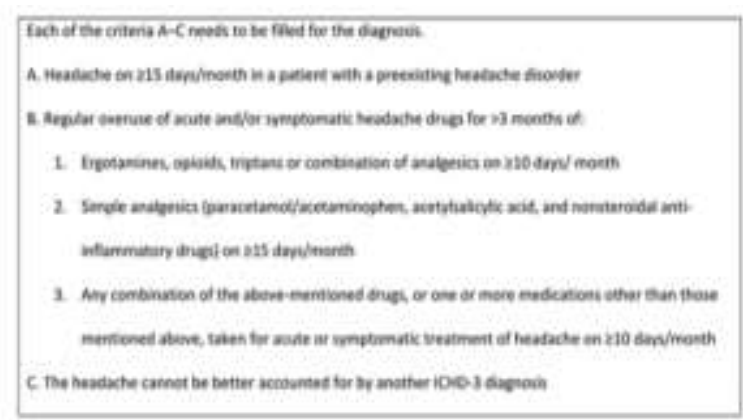

\section{KESIMPULAN}

Medication Overuse Headache $(\mathrm{MOH})$ merupakan nyeri kepala sekunder suatu perburukan dari nyeri kepala yang sudah ada sebelumnya (biasanya nyeri kepala primer). Terjadi akibat penggunaan berlebihan satu atau lebih obat-obatan untuk mengatasi serangan atau menghilangkan rasa nyeri tersebut. Klasifikasi tidak termasuk jumlah unit obat atau dosis yang digunakan, tetapi jumlah hari per bulan obat diminum. Analgesik sederhana (asetaminofen, dan asam asetilsalisilat (ASA) yang lebih jarang) dan obat antiinflamasi nonsteroid (NSAID), kafein, opioid, analgesik kombinasi, ergotamin, triptan dan barbiturat (terutama di AS dan Kanada). Diagnosis, terapi akurat dan tatalaksana komorbid harus dilakukan untuk memperbaiki kualitas hidup dan produktivitas pasien.

\section{REFERENSI}

1. Alstadhaug KB, Ofte HK, Kristoffersen ES. Preventing and treating medication overuse headache. Clinical Update. 2017. e612.

2. Boes CJ, Capobianco DJ. Chronic migraine and medication-overuse headache through the ages. Cephalalgia 2005;25:378-90.

3. Headache Classification Committee of the International Headache Society 
(IHS). The international classification of headache disorders, 3rd edition (beta version). Cephalalgia 2013;33:629-808.

4. Diener HC, Limmroth V. Medicationoveruse headache: a worldwide problem. Lancet Neurol 2004;3:475-83.

5. Evers S, Jensen R. Treatment of medication overuse headacheguideline of the EFNS headache panel. Eur J Neurol 2011;18:1115-21.

6. Hagen K, Linde M, Steiner TJ, Stovner LJ, Zwart JA. Risk factors for medication-overuse headache: an 11year follow-up study. The NordTrondelag Health Studies. PAIN 2012;153:56-61.

7. Jonsson $\mathrm{P}$, Hedenrud $\mathrm{T}$, Linde $\mathrm{M}$. Epidemiology of medication overuse headache in the general Swedish population. Cephalalgia 2011;31: 101522.

8. Lanteri-Minet M, Duru G, Mudge M, Cottrell S. Quality of life impairment, disability and economic burden associated with chronic daily headache, focusing on chronic migraine with or without medication overuse: a systematic review. Cephalalgia 2011;31:837-50.

9. Westergaard ML, Glumer C, Hansen $\mathrm{EH}$, Jensen RH. Prevalence of chronic headache with and without medication overuse: associations with socioeconomic position and physical and mental health status. PAIN 2014;155:2005-13.

10. Westergaard ML, Hansen EH, Glumer C, Olesen J, Jensen RH. Definitions of medication-overuse headache in population-based studies and their implications on prevalence estimates: a systematic review. Cephalalgia 2014;34:409-25.

11. Limmroth V, Katsarava Z, Fritsche G, Przywara S, Diener HC. Features of medication overuse headache following overuse of different acute headache drugs. Neurology 2002;59:1011-4.

12. Driel MV, Anderson E, McGuire T, Stark r. Medication overuse headache: strategies for prevention and treatment using a multidisciplinary approach. Hong Kong Med J 2018;24:617-22

13. Khu JV, Siow HC, Ho KH. Headache diagnosis, management and morbidity in the Singapore primary care setting: findings from a general practice survey. Singapore Med J 2008;49:774-9.

14. Vandenbussche N, Laterza D, Lisicki M, Lloyd J, Lupi C, Tischler H, Toom K, Vandervorst F, Quintana S, Paemeleire K, Katsarava Z. Medicationoveruse headache: a widely recognized entity amidst ongoing debate. The Journal of Headache and Pain (2018) 19:50

15. Bigal ME, Lipton RB (2008) Excessive acute migraine medication use and migraine progression. Neurology 71:1821-1828.

16. Thorlund K, Sun-Edelstein C, Druyts E et al (2016) Risk of medication overuse headache across classes of treatments for acute migraine. J Headache Pain 17(1):107

17. Paemeleire K, Crevits L, Goadsby PJ, Kaube H. Practical management of medication-overuse headache. Acta neurol. belg., 2006, 106, 43-51

18. Diener H. C., Limmroth V. Medicationove. ruse headache : a worldwide problem. Lancet Neurol., 2004, 3 (8) : 475-483.

19. Young W. B. Medication Overuse Headache. Curr. Treat. Options Neurol., 2001, 3 (2) : 181-188.

20. Fischer MA, Jan A. Medication-overuse Headache (MOH) [Updated 2019 Nov 14]. In: StatPearls [Internet]. Treasure Island (FL): StatPearls Publishing; 2019 Jan-. Available

from: 
https://www.ncbi.nlm.nih.gov/books/N

BK538150/

21. Belanger, S., Ma, W., Chabot, J. and Quirion, R. (2002) expression of calcitonin gene-related peptide, substance $\mathrm{p}$ and protein kinase $\mathrm{c}$ in cultured dorsal root ganglion neurons following chronic exposure to mu, delta and kappa opiates. Neuroscience 115: 441-453.

22. De Felice, M., Ossipov, M., Wang, R., Lai, J., Chichorro, J., Meng, I. et al. (2010) Triptan-induced latent sensitization: a possible basis for medication overuse headache. Ann Neurol 67: 325-337. 